\title{
The Capability Spectrum; locating terrorism in relation to other manifestations of political violence
}

\section{by Thomas Whelan}

\section{(cc) $\mathrm{BY}$}

This work is licensed under a Creative Commons Attribution 3.0 License.

\begin{abstract}
Terrorism is often discussed in isolation from other manifestations of political violence; however, significant understanding of the phenomenon can be gained by assessing terrorism in relation to the wider context of other forms of political violence. This paper presents a model which locates terrorism in relation to acts ranging from rioting to insurgency, based on a spectrum of increasing capabilities. This spectrum suggests that the predominantly communicative acts of terrorism locates it closely to the communicative acts of political rioting; whilst at the same time, the desire of terrorist groups to militarise further links terrorism to insurgency.
\end{abstract}

Keywords: Terrorism; Political violence; Rioting; Insurgency; Capabilities; Spectrum

\section{Introduction}

Social scientists often follow a process of examining certain phenomena, such as terrorism, in isolation in order to gain a focused understanding of a subject (Neuman 2007). Whilst this approach has much value, creating subject-specific fields such as 'Terrorism Studies', it is also worthwhile to consider how subjects such as terrorism relate to their wider context. In this case, the question of how does terrorism differ (if it does at all) from other manifestations of political violence, adopts such an approach.

In order to explore the differences between terrorism and other manifestations of political violence, this assessment will place terrorism along a spectrum of political violence (see Figure 1), ranging in capabilities (such as membership, material resources, and territorial, administrative, and security control) from low-level political violence such as rioting at one end, to insurgency at the other. This attempt will address terrorism within its wider context of other forms of political violence, and will suggest the idea that terrorism rests within an awkward 'bridging' position, between the communicative violence of rioting (Lowe 2013), and the controlled employment of militarised force in an insurgency conflict (Byman 2008).

This position will be demonstrated by firstly highlighting the fundamental similarities between terrorism and all manifestations of political violence - namely the common socio-political, grievance-inspired foundation which all forms of political violence share (Hoffman, 2006), the idea that all types of political violence are extensions of politics (von Clausewitz 1874), the communication focus of both terrorism and rioting (Schmid 2005), and the desire for militarised action terrorism and insurgency (Burleigh 2008; Guevara 2006). Attention will then turn to the differences between terrorism and rioting and insurgency respectively. This analysis will highlight the substantial desire for increasing militarisation and conflict (rather than contest) witnessed in terrorist groups for the violence to be classed within the same grouping as acts of political violence such as rioting. Whilst at the same time demonstrating terrorism to be still be firmly rooted in communication for it to be an embryonic stage of insurgency. By exploring both views it will become clear 


\section{Journal of Terrorism Research}

that terrorism rests in an awkward space between the communication-focused protest, and the militarised insurgency, and it is perhaps for this reason that terrorism gains a disproportional amount of attention and confusion, making it the intriguing phenomenon it remains today.

Figure 1: The Template for the Capability Spectrum of Political Violence

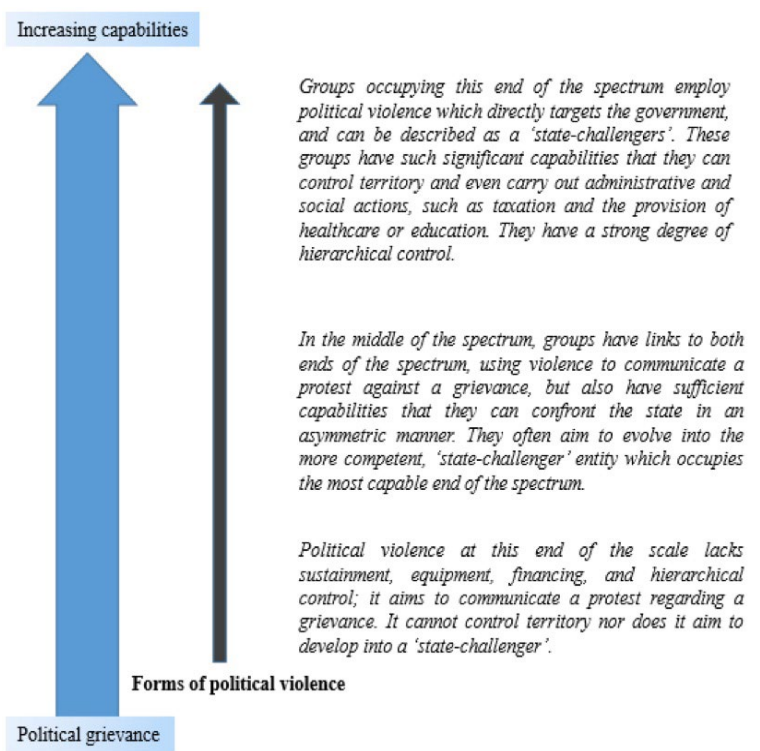

\section{Definitions}

Political violence is a realm in which definitions are often heavily contested. In general, it is any form of violence employed for a political motive, yet despite having mentioned the importance of viewing varieties of political violence as a collective, for this study it is necessary to define what is to be meant by 'terrorism', 'insurgency', and 'low-level political violence'. For this study, 'terrorism' refers to the "the premeditated use or threat of violence by individuals or subnational groups to obtain a political or social objective through the intimidation of a large audience beyond that of the immediate victims" (Enders \& Sandler in Masters 2008). Importantly, this definition does not restrict terrorism to attacks against civilians, but rather includes attacks on military or governmental personnel. The idea argued by some academics, such as Kamm (2008), that terrorism only targets civilians appears flawed, considering the 2001 attacks on 9/11 targeted both civilian (the World Trade Centre) and military individuals (the Pentagon). 'Insurgency' will refer to violence employed "to obtain political goals by an organised and primarily indigenous group... using protracted, irregular warfare and allied political technique" (Scott 1970). The adoption of this definition of insurgency is favoured due to its inclusion of irregular military tactics used over a period of time - rather than simply swift decisive force which can be seen in a coup - combined with the emphasis on the political efforts which are central to an insurgency's struggle. The 'irregular warfare' referred to is the tactic of guerrilla warfare, in which lightly to moderately armed groups aim to harass the enemy and gradually erode his will and capability through launching highly mobile, hit-and-run attacks (O’Neil 2005). Finally 'low-level' political violence, refers to "relatively spontaneous illegitimate group violence [for a political motive]", as witnessed in 


\section{Journal of Terrorism Research}

London during August 2011 (Joyce 2012; Marx 1970).

At this point it is significant to highlight Weber's thoughts on 'ideal types'. Weber's argument suggests that social scientists examine events or phenomena - such as political violence in this case-and compares them to a preconceived 'ideal type'; which is "an ideal limiting concept with which the real situation or action, is compared" (Cahnman 1965). Through this process of comparison, types of violence are categorised as to whether they appear more like an 'ideal' case 'terrorism', or an 'ideal' case of something else. Despite social scientists' disposition to isolating and classifying violence according to these 'ideal types', the reality of our world is that finding idea types which perfectly fit the specified criteria rarely exist. With this in mind, there is value in thinking of political violence as a spectrum, and one along which groups and movements can shift forwards and backwards depending on their conditions, resources, and support.

\section{Terrorism and other forms of political violence, one and the same?}

In order to examine the differences between terrorism and other manifestations of political violence, it is first necessary to acknowledge the similarities terrorism exhibits with these other forms of political violence. Despite the tendency of social scientists to view types of political violence in isolation, considerable advantages can be gained when types of political violence are examined in relation to each other. To begin, it is vital to state that all forms of political violence (from low-level riots, to communal violence, terrorism, and insurgencies), are all born out of a political grievance; a broad term which incorporates a range of grievances, from single-issue matters to wider societal marginalisation (Hoffman, 2006).

A political grievance can inspire or provoke protests, (violent or non-violent), and has been seen to do so in numerous cases throughout history. These protests can either be successful, or end through suppression and arrests, or fade away due a lack of momentum. Just as low-level acts of political violence, such as rioting, have been witnessed to emerge in response to a political grievance, other manifestations of political violence such as terrorism and insurgency have similarly been seen to arise from the same background. A good example of this can be found in the emergence of the Irish Republican Army (IRA) and the Liberation Tigers of Tamil Eelam (LTTE) following the failure of the earlier Civil Rights movements in Northern Ireland (1960s), and the decade-long protests for Tamil rights respectively (Hewitt 1981; Nadarajah and Sriskandarajah 2005). Indeed Wright-Neville and Smith's writings on terrorism as being a form of 'political rage' based off sociopolitical grievances (Smith 2009), combined with Gerry Adams' comments that "the requirements for later [IRA violence] revolution could be found within the rioting and protests of 1960s Ballymurphy" (De Baroid 2000), suggest a strong link between terrorism and rioting (or low-level political violence). This common foundation by which all manifestations of political violence are linked, supports the idea of viewing such violence as a collective rather than in isolation. This point identifies a fundamental connection between terrorism and both insurgency and lower-levels of political violence such as political rioting. Furthermore, this grievance-inspired foundation from which terrorism and other manifestations of political violence emerge, makes it possible to view all forms of political violence as extensions of political action or protest. This thought builds on Clausewitz's views on war (von Clausewitz 1997), but the point appears particularly relevant to other forms of political violence such as terrorism and rioting.

Terrorism has always been 'theatrical violence', and it is widely agreed that terrorism aims to communicate a message to a wide audience (Nacos 2002; Turk 2004). This intent shapes its character, with targets normally holding a symbolic meaning, and with attacks intending to gain attention through surprise, shock, and drama. This character of terrorist violence can been seen from the Anarchist dynamite attacks of the latter 


\section{Journal of Terrorism Research}

half of the Nineteenth Century, to the 'skyjackings' of the 1960s, and to the 2001 attacks on the World Trade Centre (Hoffman, Inside Terrorism 2006). Fundamentally, the drama of terrorist violence is based on a desire to communicate a message, and this factor locates terrorism in a very similar area to lower levels of political violence, such as rioting. Protests, non-violent or violent, are often viewed as expressions of frustration with a particular socio-political grievance, and at their very core are a communication act (Martin and Varney 2003). Violent protest, such as rioting, appears little different to terrorism when viewed through this lens, with both existing as violent acts of political communication. Whilst the message of a riot may be poorly articulated and vague (as argued by Marx's concept of rioting for a 'generalised belief' (Marx 1970)), the message still carries through to its audience in many cases. Terrorist violence is often accompanied by very clear political messages through media ranging from the symbolism of their targets, to paper manifestos, and to YouTube videos. Terrorist violence conveys a message, be it the 'religiously-inspired' terror beheadings of the 'Islamic State of Iraq and Syria' (ISIS), the declarations of war on America by Al Qaeda (Bergen 2008), or the far-right attack of Anders Breivik (Teitelbaum and Winter 2013) - all of which are political statements and protests.

At the same time, the message terrorist groups have often been seen to communicate is that 'violent action is the only way forward' (Gerwehr and Daly 2006), and this desire for militarism in order to accomplish a goal or change locates terrorism as an embryonic form of insurgency, similar to the Maoist's first stage of a guerrilla insurgency (Jones and Johnston 2013). An increase in membership and support can enable initially small terrorist groups to develop into organisations which use increasingly militarised and guerrilla tactics typically used by insurgencies. The LTTE and IRA provide valid examples of this shift towards insurgency following increasing levels of membership and weaponry sophistication. Oppenheimer highlights the IRA's impressive stores of Russian-made heavy machine guns, mortars, and semtex explosives (Oppenhiemer 2009), whilst the LTTE's force could be measured in brigades, and even included a maritime component (Katoch 1991). These capabilities are superior, or at least more 'militarised' than those an 'ideal-type' terrorist group might employ, and are more reminiscent of an insurgency than a terrorism group (Sadowski 1998); highlighting the fluidity of the spectrum on which terrorism lies. The militarism associated with terrorism the emphasis on terrorism being a 'weapon of the weak' (Azzam 2003), and the fact that terrorist groups have historically been seen to evolve into an insurgency, employing guerrilla tactics, suggests strong connections between the two forms of political violence and even prompts the question of whether terrorism is an embryonic stage of insurgency. This shift from terrorism to an insurgency employing predominantly guerrilla tactics, indicates a shift in capabilities and intentions, as the group's increased capabilities enable them to move from employing communicative violence to violence which aims to erode the opposition's will and material power. Furthermore, terrorism marks the first stage whereby a relatively small group attempts to control the violence employed for a cause, departing from the more popular, (in terms of numbers involved), yet conventionally less organised and less pre-meditated acts of rioting, and appear similar to an embryonic form of insurgency. This in part explains the emphasis terrorist groups place on recruitment (as exemplified by the 'Inspire' Al Qaeda recruitment magazines (Ibrahim 2011) and well documented YouTube videos), outbidding (Kydd and Walter 2006), and gaining material support' (Kennedy and Weimmann 2011). Indeed the frequent use of 'Army' in the nomenclature of groups, and of uniforms and insignia, hold add further weight to the idea of terrorism as an early form of sub-state conflict, and locate the phenomenon closer to other manifestations of political violence such as insurgency.

Since all forms of political violence can be viewed as extensions of politics based on a common foundation of a political grievance, it is acceptable for terrorism to be viewed as similar to both rioting (with their 


\section{Journal of Terrorism Research}

shared emphasis on communication), and to insurgency (for their shared desire for military action to bring about change). It is clear that terrorism holds core connections and similarities with various manifestations of political violence, and this allows terrorism to be viewed on a spectrum of political violence. Figure 2 attempts to form such a spectrum, and is primarily based on increasing capabilities. At the foundation, all political violence is based on a political grievance, and often a protest movement. This protest, if unanswered, can turn violent, with rioting ensuing as a form of political frustration and communication. Terrorist violence, due to its ability to be carried out by only a handful of individuals (or even a 'lone-wolf'), can emerge at any point. As explained, this can be regarded as a communication act similar to an act of rioting, yet with the potential for a desire to militarise. An increase in capabilities, such as membership and resources, can see this embryonic form of militarised action develop into an insurgency. In some instances, further increases to the capability of a group or movement can lead to the creation of a 'proto-state', where control of territory leads a group to administering a territory, providing social services, and crucially according to Kalyvas, security (Kalyvas 2006). This diagram addresses complexities caused by the fact that 'terrorist' groups such as the Provisional IRA, the LTTE, or ISIS (Wall 2014), due to their military strategies, control over territory, and large membership bases, appear more akin to an insurgency or a proto-state (in the case of the LTTE or ISIS) than to an 'ideal' terrorist group.

Figure 2. The Capability Spectrum of Political Violence

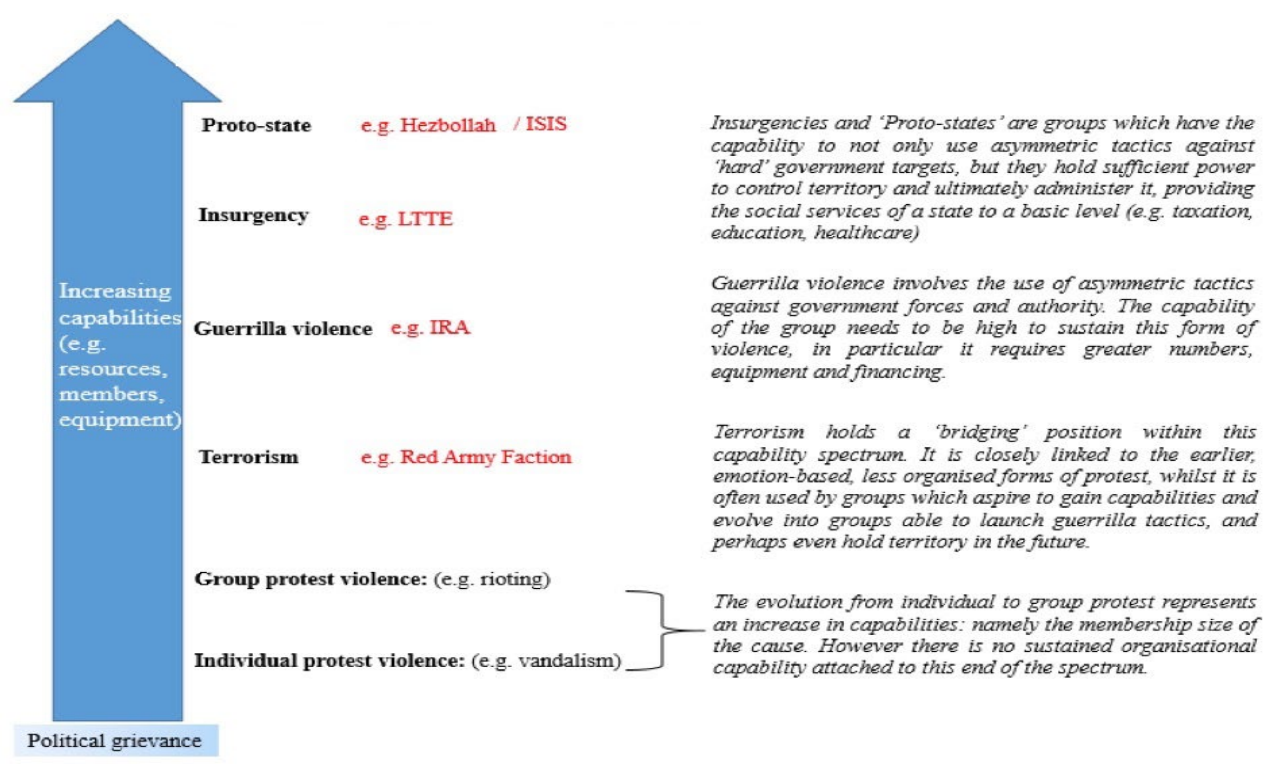

*It is important to highlight that Figure 2 does not suggest that during the lifetime of a movement a group will always progress through each stage. Indeed it is quite possible for a violent protest, with sufficient support, to move straight to an insurgency phase (the current example of the Syrian civil war being a good example of this (BBC 2014)) and never engage in acts of terrorism. Likewise, terrorism, since it requires such few numbers to be employed, does not necessarily follow violent protest, as it may indeed be the first point of violent protest a group uses, or a tactic of a proto-state.

As Figure 2 demonstrates, terrorism rests between the communicative and frustrated acts of rioting, and the militarised insurgency. In reality, many groups never leave the terrorist stage (the Red Army Faction failed to attract widespread membership and support, and numbered only a "few dozen" (Shughart 2006)). In some cases, terrorist groups such as the IRA, LTTE, and (currently) ISIL, have evolved into insurgencies or even proto-states. This violent form of communication, or potential militarised conflict, projects an image of terrorism little different to other manifestations of political violence. Certainly there is much value in 


\section{Journal of Terrorism Research}

attempting to locate terrorism in a wider context, and perhaps the most significant result of doing so is that terrorism clearly rests at the awkward position between crime and militarised conflict. This may explain why terrorism causes such debate, and is able to be viewed either as a crime or as an attack on the body politic (Norwitz 2004), and by extension, why there are differing methods of countering terrorism; namely through the criminal justice model or the war model.

\section{Differences by their similarities}

Figure 2 highlights the awkward position terrorism lies on the spectrum of political violence; a form of violent communication, but one which has the desire and potential to develop into a militarised entity (i.e. an embryonic form of insurgency). Despite the abundance of similarities terrorism shares with other manifestations of political violence, these same characteristics are the reasons which cause terrorism to be different to other manifestations of violence. In summary, the communication-based intent of terrorism, contrasts with the military-campaign focused character of insurgencies (Hammes 2007), whilst at the same time terrorist violence is often carried out by groups who have a desire for further militarisation of the struggle, and to turn the contest into a military conflict, something which is quite unlike a protest movement or even acts of rioting. Through highlighting the differences between terrorism and insurgency, and then terrorism and rioting, the differences between terrorism and other manifestations of political violence will be clear.

When addressing the differences between terrorism and insurgency, it is clear that the central concept is the level of emphasis and importance placed on communication. All insurgencies place importance on communication regarding their own support populations (Hoffman, Insurgency and Counter-Insurgency in Iraq 2006), and their opposing government, yet their focus is in line with a militarised approach - tactical gains regarding territory and resources (Marighella 1982). Terrorism is different in this regard because it focuses entirely on the communication of a message. The choice of targets an insurgency will select will often differ to that of a terrorist attack; an insurgency, using predominantly guerrilla tactics, is likely to focus on tactical locations, such as bridges, supply routes or areas on which 'hit and run' attacks can be carried out, in order to disrupt or destabilise the opposition (as demonstrated by the actions of the French Maquis throughout Occupied France (Wright 1962; Millar 2013)). Terrorist attacks normally select symbolic targets - such as urban transport (for example the London 7/7 bombings), key figures (such as police or magistrates by the Red Brigade (Moss 1983)), or governmental buildings (the Oslo bombings by Breivik (Appleton 2014)). The purpose of selecting symbolic targets is to communicate a message to a wider audience, not for tactical or strategic benefit (in terms of disrupting or defeating an opposing government). It is at this point of difference where inevitably grey areas exist and cause confusion. When insurgent movements use suicide attacks - normally labelled 'terrorism' - for communicative and military-attacking purposes, (as with the 1983 suicide attack by Hezbollah on the USA base in Lebanon, or the LTTE's use of suicide-bombers as a substitution for the lack of an Air Force (Stokke 2006)), these attacks can be located on the political violence spectrum somewhere between terrorism and insurgency. It is possible that this restriction to communication which terrorist violence adopts is the result of a lack of support and resources, as a small group of individuals, with limited capabilities and hunted by a state's law enforcement, only have the power to use shocking acts of violence to communicate a message, rather than directly challenge the state itself. This suggestion however, 


\section{Journal of Terrorism Research}

does not detract from this fundamental difference between terrorism and insurgency.

Despite the common, communication-based focus both terrorism and rioting hold, terrorism differs from this form of political violence significantly regarding the level of violence it employs. Rioting is a form of popular protest, in which some degree of low-level violence or destruction of property occurs. At worst, lives are lost, but the act of killing is not the intent of rioting. There have been historical examples, such as the PFLP skyjackings, of terrorist acts which do not aim to kill either, yet the dramatic act of violence such as bomb explosions, or the Mall massacres of Kenya (Gathara 2014) and 2008 attacks in Mumbai (Henderson 2013) are clearly different, both in terms of intent to kill and the number of casualties resulting from the attacks. Furthermore, terrorism has a degree of premeditation to it which is entirely different from rioting. Whilst some communities experience rioting at regular times of the year (such as the $12^{\text {th }}$ July in Northern Ireland), terrorist attacks are often the products of months of planning and even training for a single attack. Not only this, but the aforementioned desire to militarise shown by many groups who employ terrorist violence is very different to an act of rioting.

\section{Conclusion}

The use of a spectrum of political violence, ranging from rioting to terrorism and insurgency, has appeared an insightful method of assessing terrorism in relation to other forms of political violence. Despite a shared foundation of political grievance, and the ability of one group to emerge out of protests to employ terrorism and develop into an insurgency, terrorism has been found to hold certain similarities with both rioting (regarding their emphasis on communication), and insurgency (regarding the desire for greater militarism, recruitment, and 'Army' nomenclature). Yet it is these same characters which hold the key to terrorism's difference to these other manifestations of terrorist violence. The dominance of communication in terrorism (albeit potentially directed by a lack of capabilities) is considerably different to that of a military campaign insurgency. On the other hand, terrorism cannot be classed purely as another form of violent rioting as it employs an entirely different form of violence - one which is premeditated, shocking, and in some cases, is designed to kill, and to evolve into a military struggle. This assessment has found terrorism to exist on a spectrum of political violence between communication-based rioting, and militarised insurgency; an awkward resting point between the two, and explains the difficulty in countering terrorism as either a crime or an act of conflict.

About the author: Thomas Whelan studied at the Handa Centre for the Study of Terrorism and Political Violence at the University of St Andrews where he gained a Distinction in the MLitt in Terrorism Studies programme. As part of this degree, he spent one semester on exchange at Georgetown University, Washington DC, on their Security Studies Program, focusing on insurgency violence. His research interests focus on the relationship between terrorism and insurgency. 


\section{Journal of Terrorism Research}

\section{Bibliography}

Appleton, C. "Lone-wolf terrorism in Norway." The International Journal of Human Rights 18, no. 2 (2014): p. 127.

Azzam, M. "Weapon of the Weak." The World Today, August-September 2003: p. 10-12.

BBC, The. Syria profile: timeline. September 16th, 2014. www.bbc.co.uk/news/world-middle-eat-14703995.

Bergen, P. "Al Qaeda, the Organisation: a Five-Year Forecast." Annals of the American Academy of Political and Social Science 618 (July 2008): p. 14.

Cahnman, W. "Ideal Type Theory: Max Weber's Concept and Some of Its Derivations." The Sociological Quarterly, Summer 1965: p. 269.

Clausewitz, von. On War. Translated by J Graham. London, 1997.

De Baroid, C. Ballymurphy and the Irish War. London, 2000.

Early, B. "Larger than a Party, yet Smaller than a State: Locating Hezbollah's Place within Lebanon's State and Society." World Affairs 168, no. 3 (Winter 2006): pp. 115-128.

Enders \& Sandler in Masters, D. “"The Origin of Terrorist Threats: Religious, Separatist, or Something Else?.” Terrorism and Political Violence 20, no. 3 (2008): p. 406.

Gathara, P. Mysteries linger over Westgate Mall Attack, Al Jazeera Opinion. September 21st, 2014. http://www. aljazeera.com/indepth/opinion/2014/09/mysteries-linger-over-westgate-201492171737803205.html.

Gerwehr, S, and S Daly. Al Qaida, Terrorist Selection and Recruitment. National Security Research Division, 2006, p. 77.

Hammes, T. "Fourth Generation Warfare Evolves, Fifth Generation Emerges." Military Review, May-June 2007: p. 14.

Henderson, B. "Mumbai 26/11: Five years on, city still feels scars of devastating terrorist attack." The Telegraph, November 26th, 2013.

Hewitt, C. "Catholic Grievance, Catholic Nationalism and Violence in Northern Ireland during the Civil Rights Period: a Reconsideration.” The British Journal of Sociology, September 1981: pp. 362-380.

Hoffman, B. Inside Terrorism. New York: Columbia University Press, 2006.

Hoffman, B. "Insurgency and Counter-Insurgency in Iraq." Studies in Conflict \& Terrorism 29, no. 2 (2006): p. 108.

Ibrahim, Y, ed. Inspire, Fall 2011.

Jones, S, and P Johnston. “The future of insurgency." Studies in Conflict \& Terrorism 36, no. 1 (2013): p. 5. Joyce, J, \& Wells, H. England Riots: day of looting, arson, and violence. March 27th, 2012. www.bbc.co.uk/ news/uk-17522870.

Kalyvas, S. The Logic of Violence in Civil War. Cambridge: Cambridge University Press, 2006.

Kamm, F. “Terrorsim and Intending Evil.” Philosophy \& Public Affairs 36, no. 2 (Spring 2008): p. 157.

Katoch, A. "LTTE: Need for a Balanced Assessment." Economic and Political Weekly 26, no. 44 (November 1991): p. 2505. 


\section{Journal of Terrorism Research}

Kennedy, J, and G Weimmann. “The Strength of Weak Terrorist Ties.” Terrorism and Political Violence 23, no. 2 (2011): p. 203.

Kydd, A, and B Walter. “The Strategies of Terrorism.” International Security 31, no. 1 (Summer 2006): pp. 4980.

Marighella, C. “Minimanual of the Urban Guerrilla." In Terror and Urban Guerrillas, by J Mallin, p. 67.

Miami, 1982.

Marx, G. “Issueless Rioting.” Annals of the American Academy of Political \& Social Science 391 (1970): p. 23.

Millar, G. Maquis-an Englishman in the French Resistance. 2nd. London: The Dovecote Press, 2013.

Moss, D. "Analysing Italian political violence as a sequence of communicative acts: the Red Brigades 1970-

82." The International Journal of Social and Cultural Practice, no. 13 (May 1983): p. 97.

Nadarajah, S, \& Sriskandarajah, D. "Liberation Struggle or Terrorism? The Politics of Naming the LTTE."

Third World Quarterly 26, no. 1 (2005): p. 87.

Norwitz, J. "Combating Terrorism: with a Helmet or a Badge." In Terrorism and Counterterrorism

Understanding the New Security Environment, edited by R Howard, p. 470-481. Columbus: McGraw-Hill, 2004.

O'Neil, C. Terrorism and Insurgency: from Apocalpse to Revolution. Dulles, Virginia: Potomac Books, 2005.

Oppenhiemer, A. IRA: the bombs and the bullets, a history of deadly ingenuity. Dublin, 2009.

Sadowski, Y. “Ethnic Conflict.” Foreign Policy, no. 111 (Summer 1998): p. 13.

Scott, A, et. al. Insurgency. North Carolina, 1970.

Shughart, W. “An Analytical History of Terrorism, 1945-2000.” Public Choice 128, no. 1/2 (July 2006): p. 21.

Smith, Wright-Nevill and. "Political rage: terrorism and the politics of emoton." Global Change, Peace o Security 21, no. 1 (2009): p. 97.

Stokke, K. "Building the Tamil Eelan State: emerging state institutions and forms of governance in LTTEcontrolled areas in Sri Lanka." Third World Quarterly 27, no. 6 (2006): pp. 1021-1040.

Teitelbaum, M, and J Winter. “Islam in Europe." In The General Spread of Fertility Decline, by M, and Winter, J Teitelbaum, p. 109. Yale University Press, 2013.

Turk, A. “Sociology of Terrorism." Annual Review of Sociology 30 (2004): p. 274.

Varney, Martin and. "Nonviolence and Communication." Journal of Peace Research 40, no. 2 (2003): p. 213.

Wall, C. "Special Operations Forces." Public Lecture-The Handa Postgraduate Conference on Terrorism and Political Violence-'The Future of Terrorism \& Terrorism Studies'. St Andrews, December 5th, 2014.

Wright, G. "Reflections on the French Resistance." Political Science Quarterly 77, no. 3 (September 1962): pp. 336-349. 